EVIDENCE BASED PUBLIC HEALTH POLICY AND PRACTICE

\title{
Does the UK government's teenage pregnancy strategy deal with the correct risk factors? Findings from a secondary analysis of data from a randomised trial of sex education and their implications for policy
}

\author{
E Allen, C Bonell, V Strange, A Copas, J Stephenson, A M Johnson, A Oakley
}

J Epidemiol Community Health 2007;61:20-27. doi: 10.1136/jech.2005.040865

See end of article for authors' affiliations

Correspondence to: E Allen, Department of Primary Care and Population Sciences, Centre for Sexual Health and HIV Research, University College London, Mortimer Market Centre, off Capper Street, London WCIE 6AU, UK; e.allen@uk.imshealth.com

Accepted 22 May 2006
Background: Much of the UK government's 1999 report on teenage pregnancy was by necessity based on rather old or non-longitudinal research.

Aim: To examine the associations between risk factors identified in the report and pregnancy at or before age 16 years among young women and partners of young men using the more recent data.

Results: Socioeconomic disadvantage, being born to a teenage mother, expectation of being a teenage parent, low educational expectations and various other behaviours are potential risk factors for teenage pregnancy, as suggested by unadjusted analyses. Those who cited school as providing information on sex had a reduced risk of pregnancy at or before age 16 years, as did girls reporting easy communication with parent or guardian at baseline. Various measures of low sexual health knowledge were not associated, in either adjusted or unadjusted analyses, with increased risk of pregnancy at or before age 16 years among boys or girls.

Conclusions: A focus on many of the risk factors identified in the 1999 report is supported herein. It is suggested that knowledge may not be an important determinant, but that relationships with parents and school, as well as expectations for the future, may have important influences on teenage pregnancy. The analysis also provides new insights into risk factors for pregnancies among the partners of young men.
B efore 1999, UK government policy on teenage pregnancy has been described as being based more on moral judgements than on evidence. ${ }^{1}$ However, in June 1999 the government presented its report on teenage pregnancy ${ }^{2}$ based on the most comprehensive review to date of evidence on risk factors and recommending the development of a national strategy. The report has been regarded nationally and internationally as constituting a turning point in a move towards a more evidence-based approach to the prevention of unintended teenage pregnancy. ${ }^{3}$

However, much of the evidence available at the time of the report was from cross-sectional studies, which do not allow as clear an examination of causality as longitudinal designs. Although the cross-sectional papers cited acknowledged this fact, this was not indicated in the report itself. In addition, the report relied on evidence that was in some cases quite old and as such, because of the inevitably contextual nature of social research, may not have provided as clear a guide to current social trends as more recent research would have done.

Table $1^{4-11}$ summarises in what aspects the 1999 report relied on cross-sectional studies and on data that were more than a decade old at the time of publication of the report. Although any cut-off is of course arbitrary, we regard a decade as a reasonable guide, given likely intergenerational discontinuities. Our paper explores whether the report would have drawn attention to the same risk factors had it been able to incorporate evidence from a secondary analysis of more recent, longitudinal data from the Randomised Intervention of Pupil Peer-Led sex Education (RIPPLE) study, an ongoing cluster-randomised trial of sex education in England. ${ }^{12}$ As well as providing longitudinal and more recent information on risk factors for teenage pregnancy among young women, the data allow an examination of the risk factors for pregnancy among the female partners of young men, a matter not examined in the 1999 report. Our analysis focuses on conceptions by age 16 years, whereas the 1999 report examined those by age 18 years. However, given health concerns are greatest regarding the 16 -year-olds, ${ }^{13}$ this could be regarded as a further advantage of our analysis.

In undertaking this analysis, we are not assuming that teenage pregnancy is a negative outcome. As suggested earlier, although research indicates that pregnancies in the early teenage years may be associated with greater perinatal risk, this does not seem to be so with regard to births among older teenagers. ${ }^{13}$ We would also contend that the social harms associated with teenage births are not inevitable but are determined by societal reaction, in particular the support offered to young mothers and their children. ${ }^{14}$

\section{METHODS}

\section{Data collection}

In all, 27 coeducational secondary schools in central and southern England were recruited to the RIPPLE trial in 1997. The initial data were collected from two successive cohorts of students in 1997 and 1998 when pupils were aged 13 or 14 years. The first follow-up occurred when the participants were aged 14 or 15 years and the second, when most participants were aged 15 or 16 years, in 2001. Intervention occurred at age 13 or 14 years (in 1998 and 1999). Of the 9508 eligible pupils, $8766(92.2 \%)$ completed a questionnaire at baseline, $7770(81.7 \%)$ did so at first follow-up, and $6656(70 \%)$ at second follow-up. Consent was obtained from all parents or carers for children's participation in the study. The study was approved by the committee on the ethics of human research at

Abbreviation: RIPPLE, Randomised Intervention of Pupil Peer-Led sex Education 
Table 1 Risk factors identified in the UK government's 1999 report on teenage pregnancy and comparable factors in the Randomised Intervention of Pupil Peer-Led sex Education study

\begin{tabular}{|c|c|c|c|}
\hline \multirow[b]{2}{*}{ Factors identified } & \multicolumn{2}{|l|}{ Research cited in the government report } & \multirow[b]{2}{*}{ Comparable factor in RIPPLE study } \\
\hline & Reference & Study limitations & \\
\hline \multicolumn{4}{|l|}{ Socioeconomic status } \\
\hline Low social class, non owner-occupier housing & Botting et $a^{4}, 1998$ & Pre-1989 data & Non-privately owned housing \\
\hline Family background/relationships & & & \\
\hline $\begin{array}{l}\text { Children of teenage mothers } \\
\text { Poor communication with parents }\end{array}$ & $\begin{array}{l}\text { Kiernan }^{5}, 1995 \\
\text { Wellings et al } \\
\text { Van Zessen } 1996 \text {; Ingham and } \\
\text { Va98 }\end{array}$ & $\begin{array}{l}\text { Pre-1989 data } \\
\text { Cross-sectional; } \\
\text { cross-sectional }\end{array}$ & $\begin{array}{l}\text { Mother teenager when participant was born } \\
\text { Difficult communication with mother/father, } \\
\text { female/male guardian }\end{array}$ \\
\hline \multicolumn{4}{|l|}{ Expectations of the future/perceptions of peers } \\
\hline $\begin{array}{l}\text { Not being in education, training and work } \\
\text { post age } 16 \text { years }\end{array}$ & Bynner and Parsons ${ }^{8}, 1999$ & Pre-1989 data & $\begin{array}{l}\text { Lack of expectation of education by age } \\
20 \text { years } \\
\text { Expectation of being parent by age } 20 \text { years }\end{array}$ \\
\hline $\begin{array}{l}\text { Peer pressure to have sex early } \\
\text { Individual risk behaviours }\end{array}$ & Wellings et al ${ }^{k}, 1996$ & Cross- sectional & Believe half or more peers having sex \\
\hline Low educational attainment, truancy & $\begin{array}{l}\text { Include, Bynner and Parsons }{ }^{9} 1998 \\
\text { Croydon Community Trust }{ }^{10}, 1999\end{array}$ & Cross-sectional & Intent to skip school \\
\hline $\begin{array}{l}\text { Alcohol use } \\
\text { Sexual health knowledge }\end{array}$ & Health Education Authority/BMRB ${ }^{11}, 1998$ & Cross-sectional & Drunk monthly or more \\
\hline Low knowledge about sex & Wellings et $a^{k}, 1996$ & Cross-sectional & $\begin{array}{l}\text { Low knowledge of STIs and low knowledge of } \\
\text { timing of emergency contraceptive pill } \\
\text { Inability to identify sexual health services }\end{array}$ \\
\hline Non-school source of information about sex & Wellings et al ${ }^{\beta}, 1996$ & Cross-sectional & $\begin{array}{l}\text { Main source of information on sex does not } \\
\text { include school }\end{array}$ \\
\hline
\end{tabular}

BMRB, British Market Research Bureau; RIPPLE, Randomised Intervention of Pupil Peer-Led sex Education; STI, sexually transmitted infection.

University College London, London, UK. The research is ongoing; findings from phase one of the trial (outcomes at age 16 years) have been published..$^{15}$

\section{Data analysis}

The putative risk factors for teenage pregnancy identified in the UK government's 1999 report on teenage pregnancy were grouped into five categories relating to: socioeconomic status; family structure or relationships; expectations of the future and perceptions of peers; other risk behaviours; and sexual health knowledge (table 1). We identified comparable variables in the RIPPLE study (tables 1 and 2).

Our analysis considered the outcome "ever pregnant" $(\mathrm{n}=83)$ and "reported partner's pregnancy" $(\mathrm{n}=69)$ by second follow-up (age 15/16 years). All conceptions occurred between baseline and second follow-up, the question being asked only at second follow-up. The age of the female partners of young men was not asked. Binary measures were created for most of the risk factors, however where creation of binary measures from categorical ones would have led to loss of coherence of categories, categorical measures were retained (table 2). We used simple logistic models with all young people included in the analysis to derive crude and adjusted odds ratios (ORs) for associations between our risk factors and pregnancy at or before age 16 years. Adjusted ORs were calculated by including all variables from the other four categories of risk factor in the regression model; these being pre-hypothesised as potential confounders, risk factors from the same category were not included. This was done to minimise collinearity. As it transpired, standard errors in the model were not large and therefore collinearity was unlikely to be a problem. Within-school correlation was accounted for by using the generalised estimating methodology of Liang and Zeger $^{16}$ with an exchangeable correlation structure and robust standard errors.

Where risk factors were measured both at baseline and at first follow-up, both measures were included in the analysis. In such cases, calculation of explicit $\mathrm{p}$ values was restricted to overall tests of the association between a risk factor (at baseline and the first follow-up combined) and outcome. In addition, interpretation of the effects of the risk factors will be restricted to the overall effect of both the measure at baseline and that at follow-up 1. This is because different ORs for the same measure at the different time points simply serve as a guide as to which measure is dominant when the question has been answered at both time points.

Results are reported separately for boys and girls. Data from both trial arms were analysed together. Interactions between risk factors and trial arm were examined.

\section{RESULTS}

Tables 3 and 4 show the prevalence of risk factors and their associations with pregnancy at or before age 16 years. Some ORs differ from earlier publications owing to differences in exclusions. The following factors were significantly associated with increased risk of pregnancy at or before age 16 years in young women: non-privately owned housing; lack of expectation of being in education at age 20 years; expectation of being a parent by age 20 years; belief that over half one's peers are sexually active; intention to skip school; being drunk monthly or more; and ability to identify a sexual health service. Being born to a teenage mother was associated with pregnancy at borderline significance. Lack of expectation of being in education at age 20 years, belief that over half one's peers are sexually active and being drunk monthly or more at age 13 years remained significant on adjustment for factors from other risk categories. Young women who could communicate easily with their mother or female guardian were considerably less likely to report pregnancy at or before age 16 years. This remained significant on adjustment for factors in other categories.

The following were associated with increased risk of partner's pregnancy among young men: expectation of being a parent by age 20 years; belief that over half of one's peers are sexually active; intention to skip school; being drunk monthly or more. Being born to a teenage mother was associated with initiating pregnancy at borderline significance. Of these, only expectation of being a parent by age 20 years did not remain significant on adjustment for factors in other categories. On adjustment for factors in other categories, inability to identify a sexual health service was significantly associated with subsequent increased risk of a partner's pregnancy for young men. 
Table 2 Derivation of risk factors from the Randomised Intervention of Pupil Peer-Led sex Education study questionnaires

\begin{tabular}{|c|c|c|c|}
\hline Risk factors & Nature of measure & Questionnaire item & When asked \\
\hline \multicolumn{4}{|l|}{ Socioeconomic status } \\
\hline Non-privately owned housing & $\begin{array}{l}\text { Binary indicating response other than } \\
\text { privately owned by parents or } \\
\text { guardians; don't knows omitted }\end{array}$ & What kind of house/flat do you live in? & Baseline \\
\hline \multicolumn{4}{|l|}{ Family background/relationships } \\
\hline $\begin{array}{l}\text { Mother teenager when participant } \\
\text { was born }\end{array}$ & $\begin{array}{l}\text { Binary indicating mother's age minus young } \\
\text { person's age } \leqslant 20 \text { years }\end{array}$ & How old is your mother? & Baseline \\
\hline $\begin{array}{l}\text { Difficult communication with } \\
\text { mother/female guardian }\end{array}$ & $\begin{array}{l}\text { Binary created from } 4 \text {-point ordinal scale } \\
\text { indicating degree of ease }\end{array}$ & $\begin{array}{l}\text { Do you find it easy to talk to your mother/female } \\
\text { guardian about very private and personal things? }\end{array}$ & $\begin{array}{l}\text { Baseline/first } \\
\text { follow-up }\end{array}$ \\
\hline $\begin{array}{l}\text { Difficult communication with } \\
\text { father/male guardian }\end{array}$ & $\begin{array}{l}\text { Binary created from 4-point ordinal scale } \\
\text { indicating degree of ease }\end{array}$ & $\begin{array}{l}\text { Do you find it easy to talk to your father/male } \\
\text { guardian about very private and personal things? }\end{array}$ & $\begin{array}{l}\text { Baseline/first } \\
\text { follow-up }\end{array}$ \\
\hline \multicolumn{4}{|l|}{$\begin{array}{l}\text { Expectations of the future/ } \\
\text { perceptions of peers }\end{array}$} \\
\hline $\begin{array}{l}\text { Lack of expectation of education } \\
\text { by age } 20 \text { years }\end{array}$ & $\begin{array}{l}\text { 3-point ordinal created from } 5 \text {-point } \\
\text { ordinal indicating degree of expectation }\end{array}$ & $\begin{array}{l}\text { By the time you are } 20 \text { years old how likely do } \\
\text { you think it is that you will be at university or in } \\
\text { college or in a training scheme? }\end{array}$ & $\begin{array}{l}\text { Baseline/first } \\
\text { follow-up }\end{array}$ \\
\hline $\begin{array}{l}\text { Expectation of being a parent by } \\
\text { age } 20 \text { years }\end{array}$ & $\begin{array}{l}\text { 3-point ordinal created from } 5 \text {-point ordinal } \\
\text { indicating degree of expectation }\end{array}$ & $\begin{array}{l}\text { By the time you are } 20 \text { years old how likely do you } \\
\text { think it is that you will have a child/children? }\end{array}$ & $\begin{array}{l}\text { Baseline/first } \\
\text { follow-up }\end{array}$ \\
\hline $\begin{array}{l}\text { Believe half or more peers having } \\
\text { sex }\end{array}$ & $\begin{array}{l}\text { Binary indicating agreement that half or } \\
\text { more of peers have had sex }\end{array}$ & $\begin{array}{l}\text { How many young men/young women of your } \\
\text { age do you think have had sexual intercourse? }\end{array}$ & $\begin{array}{l}\text { Baseline/first } \\
\text { follow-up }\end{array}$ \\
\hline \multicolumn{4}{|l|}{ Individual behaviours } \\
\hline Intent to skip school & $\begin{array}{l}\text { 3-point ordinal created from 5-point scale } \\
\text { indicating degree of agreement with statement }\end{array}$ & When I get the chance I skip school & $\begin{array}{l}\text { Baseline/first } \\
\text { follow-up }\end{array}$ \\
\hline Drunk monthly or more & $\begin{array}{l}\text { Binary created from 5-point ordinal indicating } \\
\text { frequency of drunkenness }\end{array}$ & In the last year how often have you been drunk? & Baseline \\
\hline \multicolumn{4}{|l|}{ Sexual health knowledge } \\
\hline Low knowledge of STIs & $\begin{array}{l}\text { 3-point ordinal indicating number answer } \\
\text { correct of } 2 \text { questions }\end{array}$ & $\begin{array}{l}\text { Is it true that all STIs are curable? Do some STls } \\
\text { have no symptoms? }\end{array}$ & $\begin{array}{l}\text { Baseline/first } \\
\text { follow-up }\end{array}$ \\
\hline $\begin{array}{l}\text { Low knowledge of timing of } \\
\text { emergency contraceptive pill }\end{array}$ & Binary indicating correctness of answer & $\begin{array}{l}\text { Is it true that the emergency con pill will stop a } \\
\text { young woman getting pregnant if taken up to } \\
3 \text { days } / 72 \mathrm{~h} \text { after having sex? }\end{array}$ & $\begin{array}{l}\text { Baseline/first } \\
\text { follow-up }\end{array}$ \\
\hline $\begin{array}{l}\text { Inability to identify sexual health } \\
\text { services }\end{array}$ & Binary indicating ability to answer & $\begin{array}{l}\text { Can you think of a clinic/place to visit for advice } \\
\text { on sex? }\end{array}$ & $\begin{array}{l}\text { Baseline/first } \\
\text { follow up }\end{array}$ \\
\hline $\begin{array}{l}\text { Main source of information on } \\
\text { sex doesn't include school }\end{array}$ & $\begin{array}{l}\text { Binary indicating whether or not school is } \\
\text { included in answer }\end{array}$ & $\begin{array}{l}\text { From which person or from where have you } \\
\text { learnt the most about sex? }\end{array}$ & $\begin{array}{l}\text { Baseline/first } \\
\text { follow-up }\end{array}$ \\
\hline
\end{tabular}

Both young women and young men who cited school as a source of information on sex were significantly less likely to become pregnant or have a pregnant partner at or before age 16 years. However, this association did not remain significant on adjustment. No significant differences between trial arms were found.

\section{DISCUSSION}

Our results provide support for some but not all the conclusions of the UK government's 1999 report on teenage pregnancy regarding risk factors for teenage pregnancy among girls and provides new insights into risk factors for pregnancies among the partners of teenage boys. Factors found to be significantly associated among girls and boys with teenage pregnancy were peer norms, intended truancy, expectation of teenage parenthood and being drunk monthly or more, as well as being born to a teenage mother at borderline significance. Among girls, socioeconomic disadvantage and low educational expectations were also significantly associated with pregnancy. Although our results suggest that low knowledge of sexual health, as measured in our questionnaire, may not be a risk factor, they do support the conclusions of the 1999 report that gaining information about sex from school is associated with reduced risk of teenage pregnancy among girls and the sexual partners of boys.

We also found evidence that girls' ease of communication with mothers or female guardians about private and personal matters in their early teens may be protective against pregnancy by age 16 years, but that no such protection is afforded by similar communication among boys or regarding girls' or boys' communication with fathers. This contrasts slightly with the findings of previous studies. ${ }^{67}$ Although our question focused on personal or private matters in general rather than on sex in particular, we believe our question was a valid way of exploring communication about sex among this age group.

The strength of some of the above associations is striking. This is the case, for example, for associations of pregnancies among young women and partners of young men with drunkenness and with intention to skip school. This is in line with existing evidence on the clustering of risky behaviours. ${ }^{17}$ Such associations were suggested, but not fully evidenced, in the UK government's 1999 report on teenage pregnancy. In addition, our finding that the belief that half or more of one's peers are sexually active was significantly associated with increased risk of pregnancy for young women and the partners of young men provides support for the component of the teenage pregnancy strategy aiming to dispel myths about sex and give realistic information about numbers of teenagers having sex.

Another interesting finding is that participants' ability to identify a sexual health service is associated with increased risk of pregnancy in young women, but with decreased risk among partners of young men on adjustment for other factors. Reverse causality among young women may explain these differing associations, whereby young women are more likely than young men to learn of the location of a service because of earlier risk-taking. However, it is unlikely that reverse causality would have involved girls' conceptions leading them to have higher knowledge about services.

Some risk factors identified as significantly associated with pregnancy in unadjusted analysis, particularly among girls, do not remain significant after adjustment for other categories of 
Table 3 Risk factors and their association with pregnancy among young women in the Randomised Intervention of Pupil Peer-Led sex Education study data

\begin{tabular}{|c|c|c|c|c|}
\hline & \multicolumn{4}{|c|}{ Association with pregnancy in young women } \\
\hline & $\begin{array}{l}\text { Prevalence of } \\
\text { risk factor, } \mathrm{n} \text { (\%) }\end{array}$ & $\begin{array}{l}\text { Number pregnant at } \\
\text { follow-up } 2, \mathrm{n}(\%)\end{array}$ & $\begin{array}{l}\text { Unadjusted ORs } \\
(95 \% \mathrm{Cl})\end{array}$ & $\begin{array}{l}\text { Adjusted ORs } \\
(95 \% \mathrm{Cl})\end{array}$ \\
\hline \multicolumn{5}{|l|}{ Socioeconomic status } \\
\hline \multicolumn{5}{|l|}{ Housing } \\
\hline Privately owned & $1771(75.1)$ & $43(2.43)$ & 1 & 1 \\
\hline Non-privately owned & $588(24.9)$ & $27(4.59)$ & 1.97 & 0.68 \\
\hline \multicolumn{5}{|l|}{ Family structure/relationships } \\
\hline \multicolumn{5}{|l|}{ Mothers age at birth (years) } \\
\hline$\geqslant 20$ & $2335(95.0)$ & $67(2.87)$ & 1 & 1 \\
\hline$<20$ & $124(5.0)$ & $7(5.65)$ & $1.96(0.87$ to 4.47$)$ & $0.66(0.11$ to 3.77$)$ \\
\hline \multicolumn{3}{|l|}{ Communication with mother/female guardian (baseline) } & *** & ** \\
\hline Difficult & $816(30.2)$ & $40(4.90)$ & 1 & 1 \\
\hline Good & $1884(69.8)$ & $39(2.07)$ & $\begin{array}{l}0.43 \\
(0.22 \text { to } 0.85)\end{array}$ & $\begin{array}{l}0.30 \\
(0.14 \text { to } 0.66)\end{array}$ \\
\hline \multicolumn{5}{|l|}{ Communication with mother/female guardian (follow-up 1) } \\
\hline Difficult & $875(33.2)$ & $38(4.34)$ & 1 & 1 \\
\hline Good & $1758(66.8)$ & $39(2.22)$ & $\begin{array}{l}0.74 \\
(0.40 \text { to } 1.36)\end{array}$ & $\begin{array}{l}1.68 \\
(0.72 \text { to } 3.95)\end{array}$ \\
\hline \multicolumn{5}{|l|}{ Communication with father/male guardian (baseline) } \\
\hline Difficult & $2073(80.9)$ & $64(3.09)$ & 1 & 1 \\
\hline Good & 490 (19.1) & 11 (2.24) & 0.94 & 0.99 \\
\hline & & & (0.46 to 1.91$)$ & $(0.30,3.21)$ \\
\hline \multicolumn{5}{|l|}{ Communication with father/male guardian (follow-up 1) } \\
\hline Difficult & $2016(79.6)$ & $62(3.08)$ & 1 & 1 \\
\hline Good & $517(20.4)$ & $8(1.55)$ & 0.54 & 0.57 \\
\hline & & & $(0.25$ to 1.18$)$ & $(0.16$ to 2.06$)$ \\
\hline \multirow{2}{*}{\multicolumn{5}{|c|}{$\begin{array}{l}\text { Expectations of the future/perceptions of peers } \\
\text { Lack of expectation of education by age } 20 \text { years (baseline) }\end{array}$}} \\
\hline & & & *** & * \\
\hline No & $1936(72.0)$ & $48(2.48)$ & 1 & 1 \\
\hline Unsure & $690(25.7)$ & $25(3.62)$ & 1.39 & 0.68 \\
\hline & & & $(0.73$ to 2.64$)$ & $(0.20$ to 2.30$)$ \\
\hline Yes & $64(2.4)$ & $6(9.38)$ & & \\
\hline & & & (0.85 to 11.54$)$ & (0.12 to 2.04$)$ \\
\hline \multicolumn{5}{|l|}{ Lack of expectation of education by age 20 years (follow-up 1) } \\
\hline No & $1967(74.6)$ & $44(2.24)$ & 1 & 1 \\
\hline Unsure & $628(23.8)$ & $28(4.46)$ & 1.78 & 1.71 \\
\hline & & & (0.91 to 3.48$)$ & (0.68 to 4.34$)$ \\
\hline Yes & $43(1.6)$ & $5(11.63)$ & 4.56 & 8.36 \\
\hline & & & (1.80 to 11.56$)$ & (1.23 to 56.73$)$ \\
\hline \multicolumn{3}{|l|}{ Positive expectation of being a parent by age 20 years (baseline) } & $* * *$ & \\
\hline No & $1580(58.6)$ & $32(2.03)$ & 1 & 1 \\
\hline Unsure & $750(27.8)$ & $22(2.93)$ & $\begin{array}{l}1.45 \\
(0.84 \text { to } 2.52)\end{array}$ & $\begin{array}{l}1.44 \\
(0.65 \text { to } 3.20)\end{array}$ \\
\hline Yes & 366 (13.6) & $24(6.56)$ & & 1.89 \\
\hline & & & $(1.17$ to 6.44$)$ & $(0.59$ to 6.00$)$ \\
\hline \multicolumn{5}{|l|}{$\begin{array}{l}\text { Positive expectation of being a parent by age } 20 \text { years } \\
\text { (follow-up 1) }\end{array}$} \\
\hline No & 1708 (62.4) & $43(2.52)$ & 1 & 1 \\
\hline Unsure & $749(27.4)$ & $12(1.85)$ & 0.51 & 0.59 \\
\hline & & & $(0.22$ to 1.21$)$ & $(0.21$ to 1.67$)$ \\
\hline Yes & $280(10.2)$ & $22(7.86)$ & 2.24 & 1.39 \\
\hline & & & (1.12 to 4.47$)$ & (0.49 to 3.92$)$ \\
\hline \multicolumn{3}{|l|}{ Peer norms (baseline) } & $* * *$ & $\star * \star *$ \\
\hline Believe less than $1 / 2$ having sex & $2265(92.6)$ & $58(2.56)$ & 1 & 1 \\
\hline Believe $1 / 2$ or more having sex & $182(7.4)$ & 18 (9.89) & 4.68 & 2.10 \\
\hline & & & (2.23 to 9.82$)$ & (0.90 to 4.92$)$ \\
\hline \multicolumn{5}{|l|}{ Peer norms (follow-up 1) } \\
\hline Believe less than $1 / 2$ having sex & $1958(80.0)$ & $49(2.50)$ & 1 & 1 \\
\hline Believe $1 / 2$ or more having sex & $490(20.0)$ & $26(5.31)$ & 0.95 & 2.12 \\
\hline & & & $(0.61$ to 1.46$)$ & (1.21 to 3.71$)$ \\
\hline \multicolumn{5}{|l|}{ Individual behaviours } \\
\hline Intent to skip school (baseline) & & & *** & \\
\hline Unlikely & $2168(80.4)$ & $48(2.21)$ & 1 & 1 \\
\hline Ambivalent & $314(11.7)$ & $7(2.23)$ & 0.82 & 1.19 \\
\hline likely & $213(79)$ & $24(1127)$ & $\begin{array}{l}(0.36 \text { to } 1.83) \\
4.17\end{array}$ & $\begin{array}{l}(0.55 \text { to } 2.61) \\
205\end{array}$ \\
\hline Likely & $213(7.91$ & $24(11.27)$ & $\begin{array}{l}4.17 \\
(2.14 \text { to } 8.14)\end{array}$ & $\begin{array}{l}2.05 \\
(0.64 \text { to } 6.61)\end{array}$ \\
\hline
\end{tabular}


Table 3 Continued

\begin{tabular}{|c|c|c|c|c|}
\hline & \multicolumn{4}{|c|}{ Association with pregnancy in young women } \\
\hline & $\begin{array}{l}\text { Prevalence of } \\
\text { risk factor, } \mathrm{n}(\%)\end{array}$ & $\begin{array}{l}\text { Number pregnant at } \\
\text { follow-up 2, n (\%) }\end{array}$ & $\begin{array}{l}\text { Unadjusted ORs } \\
(95 \% \mathrm{CI})\end{array}$ & $\begin{array}{l}\text { Adjusted ORs } \\
(95 \% \mathrm{Cl})\end{array}$ \\
\hline \multicolumn{5}{|l|}{ Intent to skip school (follow-up 1) } \\
\hline Unlikely & $2033(76.8)$ & $46(2.26)$ & 1 & 1 \\
\hline Ambivalent & $339(12.8)$ & $9(2.65)$ & $\begin{array}{l}0.95 \\
(0.44 \text { to } 2.07)\end{array}$ & $\begin{array}{l}1.12 \\
(0.39 \text { to } 2.25)\end{array}$ \\
\hline Likely & $274(10.3)$ & $22(8.03)$ & $\begin{array}{l}2.11 \\
(1.01 \text { to } 4.12)\end{array}$ & $\begin{array}{l}2.19 \\
(0.59 \text { to } 8.07)\end{array}$ \\
\hline Drunk more than once a month at 13 & & & $* * *$ & * \\
\hline Drunk less than once a month & $2263(87.7)$ & $50(2.12)$ & 1 & 1 \\
\hline Drunk once a month or more & $316(12.3)$ & $28(8.86)$ & $\begin{array}{l}4.84 \\
\text { (3.12 to } 7.35)\end{array}$ & $\begin{array}{l}2.15 \\
(1.16 \text { to } 4.01)\end{array}$ \\
\hline \multicolumn{5}{|l|}{ Sexual health knowledge } \\
\hline \multicolumn{5}{|l|}{ Knowledge of STIs (baseline); number correct of 2} \\
\hline 0 & $524(19.3)$ & $16(3.05)$ & 1 & 1 \\
\hline 1 & $1104(40.6)$ & $32(2.90)$ & $\begin{array}{l}0.96 \\
(0.48 \text { to } 1.93)\end{array}$ & $\begin{array}{l}0.81 \\
(0.30 \text { to } 2.15)\end{array}$ \\
\hline 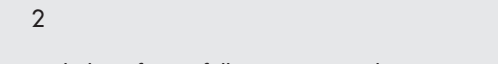 & $1090(40.1)$ & $31(2.84)$ & $\begin{array}{l}1.03 \\
(0.54 \text { to } 1.97)\end{array}$ & $\begin{array}{l}0.91 \\
(0.42 \text { to } 1.95)\end{array}$ \\
\hline \multicolumn{5}{|l|}{ Knowledge of STIs (follow-up 1); number correct of 2} \\
\hline 0 & $284(10.7)$ & $8(2.82)$ & 1 & 1 \\
\hline 1 & $886(33.4)$ & $26(2.93)$ & $\begin{array}{l}0.99 \\
(0.37 \text { to } 2.63)\end{array}$ & $\begin{array}{l}1.44 \\
(0.49 \text { to } 4.21)\end{array}$ \\
\hline-5 & $1481(55.9)$ & $43(2.90)$ & $\begin{array}{l}0.94 \\
(0.36 \text { to } 2.46)\end{array}$ & $\begin{array}{l}1.44 \\
(0.56 \text { to } 3.70)\end{array}$ \\
\hline \multicolumn{5}{|c|}{ Knowledge of timing of emergency contraceptive pill (baseline) } \\
\hline No & $2005(75.5)$ & $62(3.09)$ & 1 & 1 \\
\hline${ }^{2}$ & $652(24.5)$ & $17(2.61)$ & $\begin{array}{l}0.77 \\
(0.43 \text { to } 1.38)\end{array}$ & $\begin{array}{l}0.92 \\
(0.48 \text { to } 1.78)\end{array}$ \\
\hline \multicolumn{5}{|c|}{ Knowledge of timing of emergency contraceptive pill (follow-up 1) } \\
\hline No & $1433(55.3)$ & $35(2.44)$ & 1 & 1 \\
\hline Yes & 1158 (44.7) & $40(3.45)$ & $\begin{array}{l}1.49 \\
(0.98 \text { to } 2.26)\end{array}$ & $\begin{array}{l}1.21 \\
(0.63 \text { to } 2.33)\end{array}$ \\
\hline Ability to identify sexual health services (baseline) & & & ** & \\
\hline \multicolumn{5}{|l|}{ Ability to identify sexual health services (follow up 1) } \\
\hline No & $1235(51.7)$ & $20(1.62)$ & 1 & 1 \\
\hline Yes & 1155 (48.3) & $50(4.33)$ & $\begin{array}{l}1.99 \\
(1.22 \text { to } 3.23)\end{array}$ & $\begin{array}{l}1.44 \\
(0.75 \text { to } 2.76)\end{array}$ \\
\hline Main source of information (baseline) & & & *** & \\
\hline Does not include school & $1160(42.8)$ & $48(4.14)$ & 1 & 1 \\
\hline Includes school & $1551(57.2)$ & $31(2.00)$ & $\begin{array}{l}0.64 \\
(0.35 \text { to } 1.16)\end{array}$ & $\begin{array}{l}0.74 \\
10.33 \text { to } 1.69\end{array}$ \\
\hline \multicolumn{5}{|l|}{ Main source of information (follow up 1) } \\
\hline Does not include school & $1054(40.0)$ & $49(4.65)$ & 1 & 1 \\
\hline Includes school & $1585(60.0)$ & $28(1.77)$ & $\begin{array}{l}0.44 \\
(0.23 \text { to } 0.86)\end{array}$ & $\begin{array}{l}0.73 \\
10.26 \text { to } 2.07\end{array}$ \\
\hline
\end{tabular}

risk. This is unsurprising given that these factors are likely to intercorrelate so that adjustment for each will diminish the associations each has with pregnancy.

Our findings are subject to several limitations. Our study did not explore the effects of low expectations regarding training and occupation, which were identified in the UK government's 1999 report on teenage pregnancy as increasing the risk of teenage pregnancy. Our data are observational and so strongly suggest but cannot prove causality. In a very small number of cases, pregnancy may have occurred after baseline but before measurement of risk factors at the first follow-up. Although our data allowed an analysis of pregnancies among the partners of teenage boys, this outcome may have been reported less accurately than female participants' pregnancies, and these female partners may not themselves have been teenagers.

Attrition among study participants, although low overall, may have been somewhat higher among those conceiving. This is unlikely to have been differential with regard to our risk factors, and so, although it may have produced a slight underestimation of some associations, it will not have biased our findings. As mentioned earlier, our analysis focuses on conceptions by age 16 years, whereas the 1999 report examined those by age 18 years. This is, however, unlikely to explain our differing findings regarding the effects of knowledge on risk of teenage pregnancy, and current evidence suggests that our outcome is a better guide to the health of mother and baby. ${ }^{13}$ As in studies referenced in the UK government review, our analysis only examined those children whose mothers were teenagers at the time of their birth, as opposed to including children whose mothers were teenagers at the time of the birth of an older sibling but not at the time of that child's birth. Our estimate of the effect of the former may be smaller than an estimate derived from examination of the latter. Interestingly, our results are supported by a recent analysis of UK girls born in 1970, which found an association between being born to a teenage mother and girls' own teenage pregnancies, after adjustment for socioeconomic status. ${ }^{18}$ Finally, our finding that 
Table 4 Risk factors and their association with pregnancy among partners of young men in Randomised Intervention of Pupil PeerLed sex Education study data

\begin{tabular}{|c|c|c|c|c|}
\hline & \multicolumn{4}{|c|}{ Association with pregnancy among partners of young men } \\
\hline & $\begin{array}{l}\text { Prevalence of } \\
\text { risk factor, } n(\%)\end{array}$ & $\begin{array}{l}\text { Number pregnant at } \\
\text { follow-up 2, } \mathrm{n}(\%)\end{array}$ & $\begin{array}{l}\text { Unadjusted OR } \\
(95 \% \mathrm{Cl})\end{array}$ & $\begin{array}{l}\text { Adjusted OR } \\
\text { (95\% Cl) }\end{array}$ \\
\hline \multicolumn{5}{|l|}{ Socioeconomic status } \\
\hline \multicolumn{5}{|l|}{ Housing } \\
\hline Privately owned & $1727(75.1)$ & $37(2.14)$ & 1 & 1 \\
\hline Non-privately owned & $572(24.9)$ & $18(3.15)$ & $\begin{array}{l}1.51 \\
(0.82 \text { to } 2.77)\end{array}$ & $\begin{array}{l}1.05 \\
(0.32 \text { to } 3.40)\end{array}$ \\
\hline \multicolumn{5}{|l|}{ Family structure/relationships } \\
\hline \multicolumn{5}{|l|}{ Mothers age at birth (years) } \\
\hline$\geqslant 20$ & 1980 (94.6) & $45(2.27)$ & 1 & 1 \\
\hline$<20$ & $114(5.4)$ & $7(6.14)$ & $\begin{array}{l}2.76 \\
(0.99 \text { to } 7.68)\end{array}$ & $\begin{array}{l}0.47 \\
(0.07 \text { to } 3.011)\end{array}$ \\
\hline \multicolumn{5}{|c|}{ Communication with mother/female guardian (baseline) } \\
\hline Difficult & $1380(52.5)$ & $34(2.46)$ & 1 & 1 \\
\hline Good & $1248(47.5)$ & $32(2.56)$ & $\begin{array}{l}0.98 \\
(0.43 \text { to } 2.25)\end{array}$ & $\begin{array}{l}0.93 \\
(0.31 \text { to } 2.81)\end{array}$ \\
\hline \multicolumn{5}{|c|}{ Communication with mother/female guardian (follow-up 1) } \\
\hline Difficult & $1495(57.4)$ & $32(2.14)$ & 1 & 1 \\
\hline Good & $1108(42.6)$ & $28(2.53)$ & $\begin{array}{l}1.20 \\
(0.61 \text { to } 2.35)\end{array}$ & $\begin{array}{l}1.21 \\
(0.47 \text { to } 3.13)\end{array}$ \\
\hline \multicolumn{5}{|c|}{ Communication with father/male guardian (baseline) } \\
\hline Difficult & $1373(53.3)$ & $32(2.33)$ & 1 & 1 \\
\hline Good & $1202(46.7)$ & $31(2.58)$ & $\begin{array}{l}0.90 \\
(0.46 \text { to } 1.75)\end{array}$ & $\begin{array}{l}0.54 \\
(0.24 \text { to } 1.21)\end{array}$ \\
\hline \multicolumn{5}{|c|}{ Communication with father/male guardian (follow-up 1) } \\
\hline Difficult & $1452(56.9)$ & $30(2.07)$ & 1 & 1 \\
\hline Good & $1101(43.1)$ & $30(2.72)$ & $\begin{array}{l}1.38 \\
(0.67 \text { to } 2.84)\end{array}$ & $\begin{array}{l}2.07 \\
(0.91 \text { to } 4.68)\end{array}$ \\
\hline \multirow{2}{*}{\multicolumn{5}{|c|}{$\begin{array}{l}\text { Expectations of the future/perceptions of peers } \\
\text { Lack of expectation of education by age } 20 \text { years (baseline) }\end{array}$}} \\
\hline & & & & \\
\hline No & $1753(66.5)$ & $47(2.68)$ & 1 & 1 \\
\hline Unsure & $779(29.5)$ & $17(2.18)$ & $\begin{array}{l}0.88 \\
(0.53 \text { to } 1.48)\end{array}$ & $\begin{array}{l}0.62 \\
(0.27 \text { to } 1.43)\end{array}$ \\
\hline Yes & $105(4.0)$ & $3(2.86)$ & $\begin{array}{l}1.06 \\
(0.31 \text { to } 3.61)\end{array}$ & $\begin{array}{l}1.24 \\
(0.23 \text { to } 6.77)\end{array}$ \\
\hline \multicolumn{4}{|c|}{ Lack of expectation of education by age 20 years (follow-up 1) } & NA \\
\hline No & $1760(66.4)$ & $40(2.27)$ & 1 & \\
\hline Unsure & $794(30.0)$ & $20(2.52)$ & $\begin{array}{l}1.22 \\
(0.71 \text { to } 2.10)\end{array}$ & \\
\hline Yes & $95(3.6)$ & $4(4.21)$ & $\begin{array}{l}2.06 \\
(0.68 \text { to } 6.21)\end{array}$ & \\
\hline \multicolumn{3}{|c|}{ Positive expectation of being a parent by age 20 years (baseline) } & * & \\
\hline No & $1267(47.5)$ & $23(1.82)$ & 1 & 1 \\
\hline Unsure & $929(34.8)$ & $21(2.26)$ & $\begin{array}{l}1.27 \\
(0.50 \text { to } 3.23)\end{array}$ & $\begin{array}{l}1.22 \\
(0.40 \text { to } 3.69)\end{array}$ \\
\hline Yes & $473(17.7)$ & $22(4.65)$ & 2.45 to 5.46$)$ & $\begin{array}{l}0.72 \\
(0.21 \text { to } 2.49)\end{array}$ \\
\hline \multicolumn{5}{|c|}{ Positive expectation of being a parent by age 20 years (follow-up 1) } \\
\hline No & $1512(57.0)$ & $33(2.18)$ & 1 & 1 \\
\hline Unsure & $859(32.4)$ & $17(1.98)$ & $\begin{array}{l}0.81 \\
(0.35 \text { to } 1.89)\end{array}$ & $\begin{array}{l}0.65 \\
(0.28 \text { to } 1.52)\end{array}$ \\
\hline Yes & $282(10.6)$ & $14(4.96)$ & $\begin{array}{l}1.65 \\
(0.81 \text { to } 3.32)\end{array}$ & $\begin{array}{l}1.87 \\
(0.42 \text { to } 8.20)\end{array}$ \\
\hline \multicolumn{3}{|l|}{ Peer norms (baseline) } & $* * *$ & * \\
\hline Believe less than $1 / 2$ having sex & $2253(94.0)$ & $51(2.26)$ & 1 & 1 \\
\hline Believe $1 / 2$ or more having sex & $145(6.0)$ & $11(7.59)$ & $\begin{array}{l}3.71 \\
1189+0.311\end{array}$ & 2.77 \\
\hline \multicolumn{5}{|l|}{ Peer norms (follow up 1) } \\
\hline Believe less than $1 / 2$ having sex & $2038(83.4)$ & $42(2.06)$ & 1 & 1 \\
\hline Believe $1 / 2$ or more having sex & $405(16.6)$ & $17(4.20)$ & $\begin{array}{l}1.67 \\
(0.86 \text { to } 3.25)\end{array}$ & $\begin{array}{l}2.17 \\
(0.90 \text { to } 5.24)\end{array}$ \\
\hline \multicolumn{5}{|l|}{ Individual behaviours } \\
\hline \multicolumn{3}{|l|}{ Intent to skip school (baseline) } & $* \star *$ & *** \\
\hline Unlikely & $2024(76.0)$ & $40(1.98)$ & 1 & 1 \\
\hline $\begin{array}{l}\text { Unlikely } \\
\text { Ambivalent }\end{array}$ & $377(14.2)$ & $16(4.24)$ & $\begin{array}{l}1.45 \\
(0.69 \text { to } 3.02)\end{array}$ & $\begin{array}{l}1.77 \\
(0.48 \text { to } 6.47)\end{array}$ \\
\hline Likely & $263(9.9)$ & $11(4.18)$ & $\begin{array}{l}1.27 \\
(0.67 \text { to } 2.41)\end{array}$ & $\begin{array}{l}2.93 \\
(0.94 \text { to } 9.15)\end{array}$ \\
\hline \multicolumn{5}{|l|}{ Intent to skip school (follow up 1) } \\
\hline Unlikely & $1960(73.7)$ & $33(1.68)$ & 1 & 1 \\
\hline Ambivalent & $367(13.8)$ & $11(3.00)$ & 1.67 & 1.68 \\
\hline Likely & $331(12.5)$ & $20(6.04)$ & $\begin{array}{l}3.51 \\
(1.97 \text { to } 6.25)\end{array}$ & $\begin{array}{l}1.93 \\
(0.60 \text { to } 6.24)\end{array}$ \\
\hline
\end{tabular}


Table 4 Continued

\begin{tabular}{|c|c|c|c|c|}
\hline & \multicolumn{4}{|c|}{ Association with pregnancy among partners of young men } \\
\hline & $\begin{array}{l}\text { Prevalence of } \\
\text { risk factor, } \mathrm{n}(\%)\end{array}$ & $\begin{array}{l}\text { Number pregnant at } \\
\text { follow-up 2, n (\%) }\end{array}$ & $\begin{array}{l}\text { Unadjusted OR } \\
(95 \% \mathrm{Cl})\end{array}$ & $\begin{array}{l}\text { Adjusted OR } \\
(95 \% \mathrm{Cl})\end{array}$ \\
\hline Drunk >once a month at age 13 years & & & *** & *** \\
\hline Drunk < once a month & $2364(89.1)$ & $46(1.95)$ & 1 & 1 \\
\hline Drunk $\geqslant$ once a month & $290(10.9)$ & $19(6.55)$ & $\begin{array}{l}3.43 \\
(2.14 \text { to } 5.52)\end{array}$ & $\begin{array}{l}3.86 \\
(1.74 \text { to } 8.57)\end{array}$ \\
\hline 0 & $607(22.4)$ & $12(1.98)$ & 1 & 1 \\
\hline 1 & $1040(38.4)$ & $26(2.50)$ & $\begin{array}{l}1.38 \\
(0.64 \text { to } 2.95)\end{array}$ & $\begin{array}{l}0.93 \\
(0.33 \text { to } 2.57)\end{array}$ \\
\hline 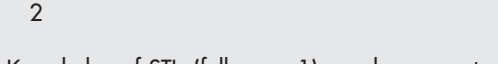 & $1058(39.1)$ & $29(2.74)$ & $\begin{array}{l}1.49 \\
(0.68 \text { to } 3.30)\end{array}$ & $\begin{array}{l}0.86 \\
(0.30 \text { to } 2.44)\end{array}$ \\
\hline \multicolumn{5}{|l|}{ Knowledge of STIs (follow-up 1); number correct of 2} \\
\hline 0 & $359(13.4)$ & $7(1.95)$ & 1 & 1 \\
\hline 1 & $876(32.8)$ & $23(2.63)$ & $\begin{array}{l}1.10 \\
(0.36 \text { to } 3.41)\end{array}$ & $\begin{array}{l}3.58 \\
(0.57 \text { to } 22.66)\end{array}$ \\
\hline $\mathrm{H} \mathrm{C}$ & $1435(53.7)$ & $34(2.37)$ & $\begin{array}{l}0.99 \\
(0.40 \text { to } 2.44)\end{array}$ & $\begin{array}{l}3.22 \\
(0.59 \text { to } 17.52)\end{array}$ \\
\hline \multicolumn{5}{|c|}{ Knowledge of timing of emergency contraceptive pill (baseline) } \\
\hline No & $2224(86.6)$ & $56(2.52)$ & 1 & 1 \\
\hline 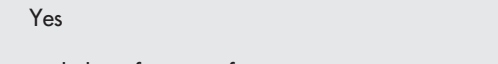 & $345(13.4)$ & $8(2.32)$ & $\begin{array}{l}0.46 \\
(0.30 \text { to } 1.93)\end{array}$ & $\begin{array}{l}1.15 \\
(0.45 \text { to } 2.88)\end{array}$ \\
\hline \multicolumn{5}{|c|}{ Knowledge of timing of emergency contraceptive pill (follow-up 1) } \\
\hline No & $1968(77.3)$ & $44(2.24)$ & 1 & 1 \\
\hline Yes & $579(22.7)$ & $18(3.11)$ & $\begin{array}{l}1.52 \\
(0.75 \text { to } 3.07)\end{array}$ & $\begin{array}{l}2.24 \\
(0.96 \text { to } 5.24)\end{array}$ \\
\hline Ability to identify sexual health services (baseline) & & & & ** \\
\hline No & $1854(78.3)$ & $49(2.64)$ & 1 & 1 \\
\hline ( & $513(21.7)$ & $12(2.34)$ & $\begin{array}{l}0.75 \\
(0.42 \text { to } 1.37)\end{array}$ & $\begin{array}{l}0.58 \\
(0.27 \text { to } 1.25)\end{array}$ \\
\hline \multicolumn{5}{|l|}{ Ability to identify sexual health services (follow-up 1) } \\
\hline No & $1504(64.9)$ & $31(2.06)$ & 1 & 1 \\
\hline Yes & $812(35.1)$ & $20(2.46)$ & $\begin{array}{l}0.99 \\
(0.66 \text { to } 1.49)\end{array}$ & $\begin{array}{l}0.32 \\
(0.14 \text { to } 0.69)\end{array}$ \\
\hline Main source of information (baseline) & & & * & * \\
\hline Does not include school & $997(37.6)$ & $29(2.91)$ & 1 & 1 \\
\hline Includes school & $1654(62.4)$ & $28(2.30)$ & $\begin{array}{l}1.10 \\
(0.25 \text { to } 1.76)\end{array}$ & $\begin{array}{l}2.04 \\
(0.86 \text { to } 4.80)\end{array}$ \\
\hline \multicolumn{5}{|l|}{ Main source of information (follow-up 1) } \\
\hline Does not include school & $939(35.5)$ & $31(3.30)$ & 1 & 1 \\
\hline Includes school & $1704(64.5)$ & $32(1.88)$ & $\begin{array}{l}0.43 \\
(0.25 \text { to } 0.76)\end{array}$ & $\begin{array}{l}0.44 \\
(0.21 \text { to } 0.93)\end{array}$ \\
\hline
\end{tabular}

young people's expectations concerning parenthood do not correspond to their actual experiences is interesting but does not indicate that the former are invalid measures; rather they are valid indicators of perspectives at a point in time.

In terms of policy, our findings provide broad support for the multi-faceted approach to teenage pregnancy recommended in the 1999 report. We would suggest that socioeconomic disadvantage, low educational expectations, truancy and alcohol use are important influences on teenage pregnancy as well as other negative outcomes. ${ }^{17}$ It is noteworthy that these factors are now being dealt with in the UK by government initiatives focused on young people's personal development and education. $^{19}$ Our findings provide evidence to support the implementation of policies aiming to improve communication between young women and their parents or guardians about sex, such as the "Time to Talk" initiative. Our findings that school is a key source of sexual health information but that none of our five indicators of sexual health knowledge is a risk factor for pregnancy support the view that sex education should focus on skills and emotional literacy as well as knowledge, as recommended in the UK government guidance. ${ }^{20}$ It might also suggest that delivery of sex education should not, in the absence of other action, be regarded as sufficient for reducing teenage pregnancies, again supporting the multifaceted approach taken in the UK.

Finally, we would like to emphasise that the aim of this paper has been to examine the implications of our own data for policy and practice concerning teenage pregnancy. Although beyond the remit of this study, we strongly recommend that policy in this area would benefit from a broader review of recent longitudinal evidence on risk factors using systematic methods of search and study appraisal.

\section{Authors' affiliations}

E Allen, A Copas, J Stephenson, A M Johnson, Department of Primary Care and Population Sciences, Centre for Sexual Health and HIV Research, University College London, London, UK

C Bonell, Public and Environmental Health Research Unit, London School of Hygiene and Tropical Medicine, London, UK

V Strange, A Oakley, Social Science Research Unit, Institute of Education, University of London, London, UK

Competing interests: None. 


\section{What is already known on this topic}

- The 1999 UK government's report on teenage pregnancy concluded that the following were risk factors for pregnancies among teenage girls: socioeconomic disadvantage, having been oneself the child of a teenage parent, poor communication with parents, not being in education, training or work after age 16 years, peer pressure to have sex early, educational problems such as low achievement and truancy, alcohol use, low knowledge about sexual health, and learning about sex from sources other than school

- However, these conclusions were based on evidence that was rather old or from cross-sectional studies, which are not the best guide to current trends

\section{What this study adds}

- Our analysis of recent longitudinal data suggests that most of the above factors are associated with under16 year pregnancies, but casts doubt on whether low knowledge about sexual health is significant

- Our findings suggest that ease of communication with parents/guardians is protective against girls, pregnancy by age 16 years but that this is not so regarding boys initiating pregnancies before age 16 years

- We identify expectation of becoming a teenage parent and of not being in education at age 20 years as additional risk factors

- Our findings support a policy of dealing with multiple influences on teenage pregnancy including recent initiatives addressing communication, personal development and education

\section{REFERENCES}

1 Burtney E, Fullerton D, Hosie A. Policy developments in the United Kingdom. In: Burtney E, Duffy M, eds. Young people and sexual health: individual, social and policy contexts. Basingstoke: Palgrave Macmillan, 2004:38-59.

2 Social Exclusion Unit. Teenage pregnancy. London: HMSO, 1999.

3 House of Commons Health Committee. Sexual health: third report of session 2002/2003 1. London: HMSO, 2003.

4 Botting $B$, Rosato $M$, Wood R. Teenage mothers and the health of their children. Popul Trends 1998;93:19-28.

5 Kiernan K. Transition to parenthood: young mothers, young fathers-associated factors and later life experiences. Welfare State Programme, Discussion paper WSP/113. London: LSE, 1995.

6 Wellings K, Wadsworth J, Johnson A, et al. Teenage sexuality, fertility and life chances. A report prepared for the Department of Health using data from the National Survey of Sexual Attitudes and Lifestyles. London: London School of Hygiene and Tropical Medicine, 1996.

7 Ingham R, Van Zessen G. From cultural contexts to interactional competencies: a European Comparative study. London: Social Exclusion Unit, 1999.

8 Bynner J, Parsons S. Young people not in employment, education or training and social exclusion. Analysis of the British Cohort study 1970 for the Social Exclusion Unit. London: Social Exclusion Unit, 1999.

9 Bynner J, Parsons S. Survey in their response to the Social Exclusion Unit's consultation on teenage parenthood. London: SEU, 1999.

10 Croydon Community Trust. The health of young mothers in Fieldway and New Addington. London: SEU, 1999.

11 Health Education Authority/British Market Research Bureau. Sexual health matters survey. London: HEA, 1998.

12 Stephenson JM, Oakley A, Johnson AM, et al. A school based randomised controlled trial of peer-led sex education. Control Clin Trials 2003;24:643-57.

13 Hoffman SD. Teenage childbearing is not so bad after all-is it? A review of new literature. Family Plann Perspect 1998;30:236-9.

14 Bonell CP. Why is teenage pregnancy conceptualized as a social problem? A review of quantitative research from the USA and UK. Cult Health Sex 2004;6:1-18.

15 Stephenson JM, Strange V, Forrest S, et al. A Randomised Intervention trial of PuPil-Led sex Education in England (RIPPLE). Lancet 2004;364:338-46.

16 Liang KY, Zeger SL. Longitudinal data analysis using generalised estimating models. Biometrika 1986;73:13-22.

17 Resnick MD, Bearman PS, Blum RW, et al. Protecting adolescents from harm findings from the National Longitudinal Study on Adolescent Health. JAMA 1997;278:823-32.

18 Pevalin D. Outcomes in childhood and adulthood by mother's age at birth: evidence from the 1970 British Cohort Study, ISER Working Paper 2003/31. Colchester: Institute for Social and Economic Research, University of Essex, 2003.

19 Wiggins M, Bonell CP, Sawtell M, et al. Evaluation of the young people's development programme. First interim report. London: Social Science Research Unit, Institute of Education, University of London, 2004.

20 Department for Education and Employment. Sex and relationships education guidance. DFEE 0116/2000. London: HMSO, 2000:222.

\section{APHORISM OF THE MONTH}

\section{"Starting where they are is the key to providing for underserved groups"}

1 ake contact, maintain contact, make changes" was the principle behind the first large-scale syringe exchange programme in England, developed by health promoter Howard Seymour in 1985. Unless you are in contact with groups whose behaviour is problematic, you can do nothing about it. This means that services have to be open access, nonjudgemental, and consumer friendly. Maintaining contact is the key to a therapeutic relationship in which changes can be made when the client is ready. The harm reduction approach to drug and sexual health issues has often been resisted by those whose style is paternalistic. Public Health practitioners should remember Lowell Levin's aphorism that sometimes it is necessary to forget your principles and do the right thing. ${ }^{1}$ The harm reduction approach on Merseyside essentially kept the HIV virus out of the drug injecting population. As applied to the vexed issue of teenage pregnancy, it has led to falls of $25 \%$ and more.

Lowell Levin and JRA

\section{REFERENCE}

1 Ashton JR. "Sometimes it is necessary to forget your principles and do the right thing" (Lowell Levin). J Epidemiol Community Health 2004;58:264. 